\title{
Model of the hospitality industry development based on the cost approach
}

\author{
Oksana Pirogova ${ }^{1,{ }^{*}}$ and Vilena Zasenko ${ }^{1}$ \\ ${ }^{1}$ Peter the Great St. Petersburg Polytechnic University, Institute of Industrial Management, \\ Economics and Trade, Graduate School of Service and Trade, 29 Polytechnicheskaya str., 195251, St. \\ Petersburg, Russia
}

\begin{abstract}
Apartments have become a new trend in the market over the past few years. This type of real estate is becoming more and more popular every year, both among investors and tourists. The purpose of the article is to make a forecast of prices for apartments in St. Petersburg. Research methods: description, comparison, analogy, generalization and analysis. In the course of the study, the dynamics of changes in prices per square meter of apartments in St. Petersburg for 2014-2019 is considered; the main factors influencing the price index of apartments in St. Petersburg are identified. The influence of the identified factors on the price indicator is analysed on the basis of multiple linear regression. The study showed that almost all factors have a fairly strong relationship with the resulting indicator. The most significant factors are identified, on the basis of which the final model of the cost of apartments is built. On the basis of the exponential smoothing method, an assessment of changes in factors in the forecast period was made and a forecast of apartment prices was made based on the obtained values. The study shows that apartment prices will rise in the coming period. The forecast of the cost of service apartments developed by the authors can have a positive effect when conducting real estate transactions in St. Petersburg.
\end{abstract}

\section{Introduction}

Over the past few years, the hotel business sector in Russia has undergone significant changes. Significantly improved the quality of service, interior decoration, more attention was paid to the qualifications of the staff [1]. The construction of new hotel complexes with developed infrastructure, equipped territory and convenient transportation, is one of the most important features of the modern hotel business in Russia at the moment. In addition, there is a tendency to ensure accessibility of services for guests with a low level of income [2].

Currently, there are a huge number of places to stay during various trips or travels [3]. In Russia, the modern hotel business is represented by the following main types of premises:

1) Hotel complexes;

\footnotetext{
* Corresponding author: kafedra17@,rambler.ru
} 
2) Pension hotels;

3) Hotels with medical services;

4) Apartments and apart-hotels;

5) Hostels.

Apart hotels have gained great popularity over the past few years. The format of apartments has long been present in developed foreign real estate markets, so the appearance and their development in domestic markets is quite natural [4]. In St. Petersburg, the apartment market is a fairly new thing, such projects are no more than five years old. But, despite such a short period of time, interest in buying apartments is constantly growing. The number of new projects and sales volumes are breaking records [5]. The attractiveness of this type of real estate is explained by their placement in places with developed infrastructure, equipped territory and convenient transportation. In addition, apartment prices are lower than apartments, and the class of such housing implies a completely different level of comfort.

There are four apartment formats: service, non-service, recreational and elite [6]. At the peak - service apartments for rent. This is confirmed by the dynamics of demand for apartments by formats (Fig. 1).

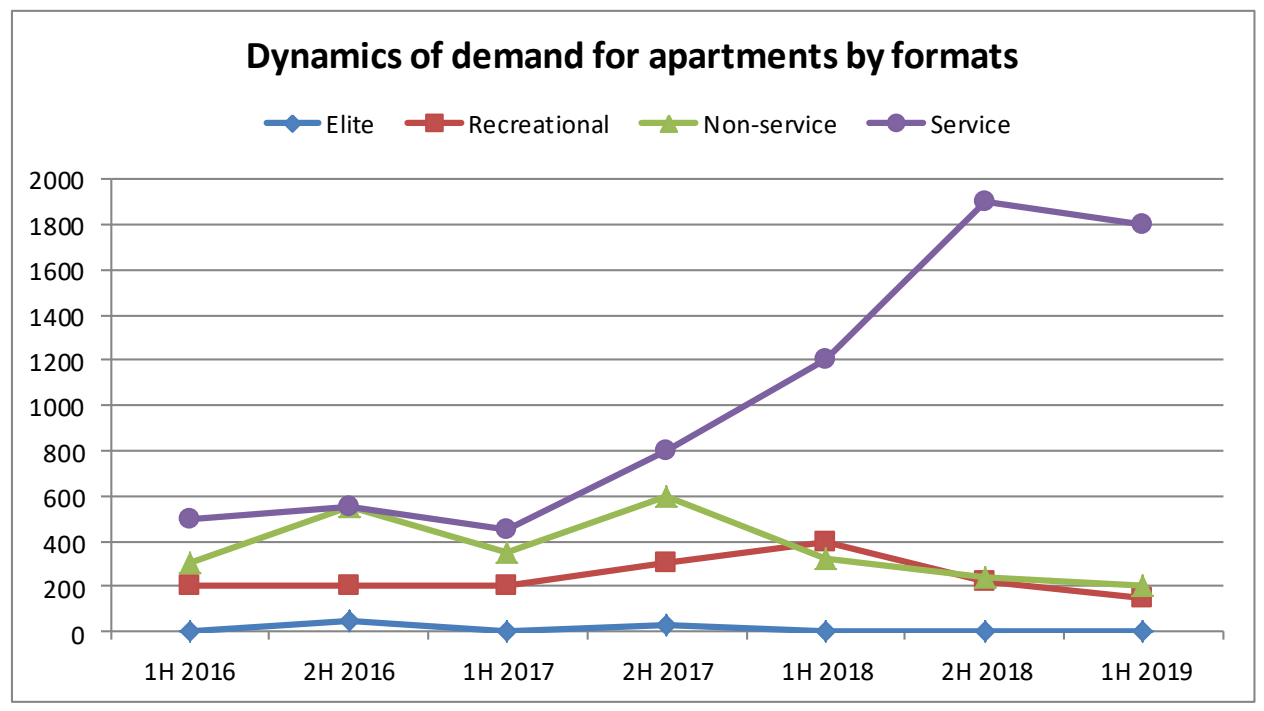

Fig. 1. The dynamics of demand for apartments by formats.

In addition, it should be noted that since the beginning of 2019, 2,200 apartments have been sold, which is $11 \%$ higher than in the first half of 2018. The share of service apartments in the sales structure was $85 \%$ [4]. In addition, in this format, an increase in sales was observed by $42 \%$ compared to the first half of 2018 [7].

In order to understand the reason for such a demand for this segment of real estate on the St. Petersburg market, it is necessary to get acquainted with the main problems of the development of apart-hotels, to assess their advantages and disadvantages.

\section{Materials and methods}

Every year the number of apart-hotels in St. Petersburg is growing, and with it the load of rooms is increasing. This is evidenced by statistics. In Figure 2, it can be seen that in just 4 years, the total supply area of apart-hotels increased more than 3 times (from 3 to 11.1 
thousand $\mathrm{m} 2$ ). A good occupancy of rooms indicates a steady and growing demand for apart-hotels (Figure 3).

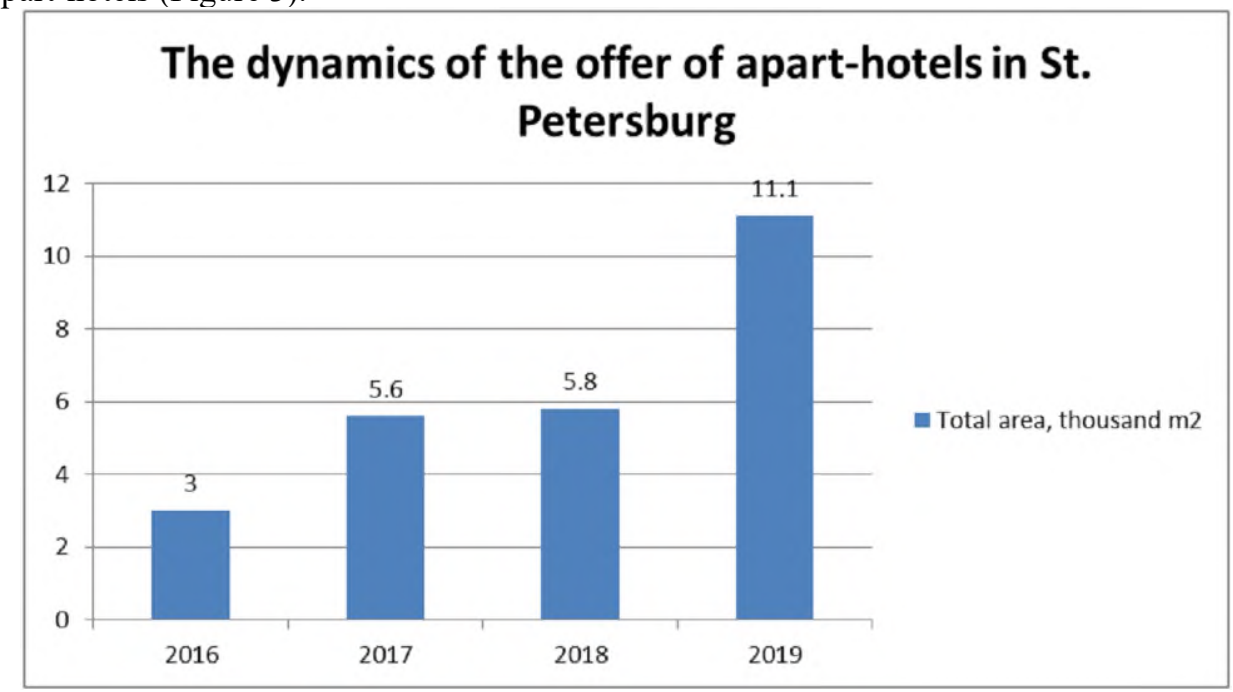

Fig. 2. The dynamics of the offer of apart-hotels in St. Petersburg.

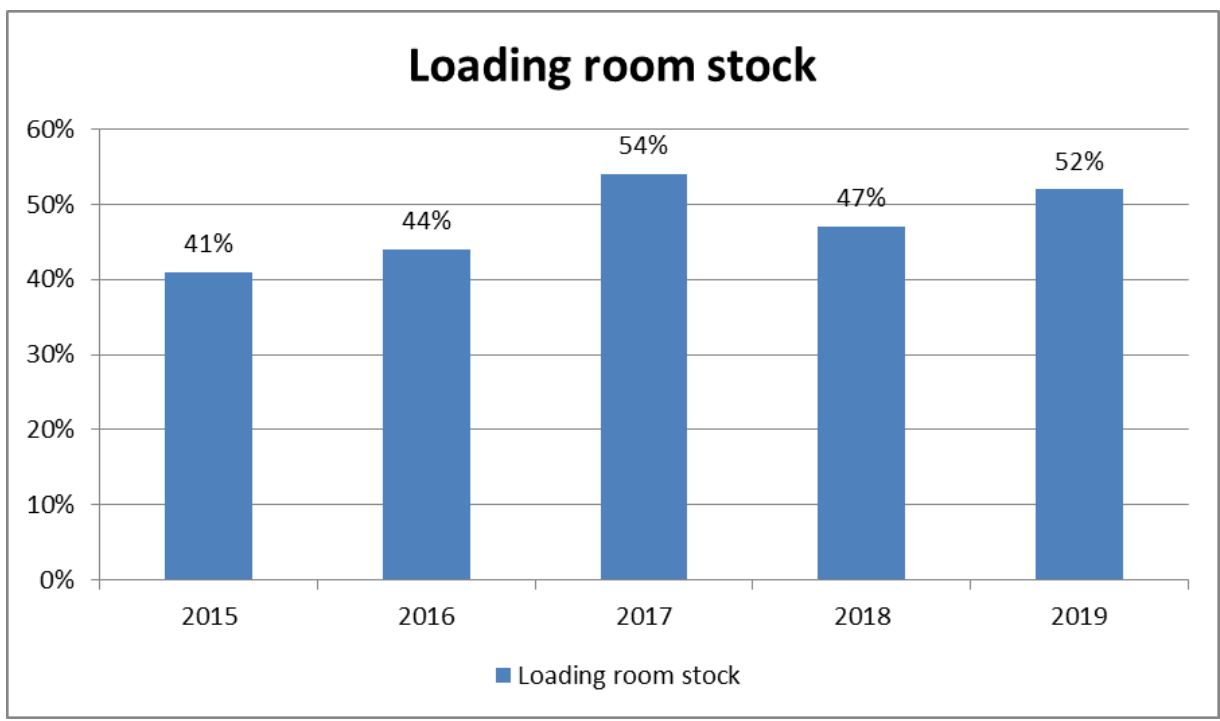

Fig. 3. Loading room stock of apart-hotels of St. Petersburg.

According to forecasts, by 2021, according to the number of rooms in St. Petersburg, traditional hotels and apart-hotels will be in approximately the same weight category. Moreover, hotels, according to analysts, will lose competition, as visiting tourists or city guests increasingly prefer to live in separate apartments and in rooms in apart-hotels, as this is much cheaper and more comfortable [7]. It should be noted that the level of service provided in apart-hotels is practically not inferior to the service provided in hotels (table 1).

In addition, there are a number of advantages of accommodation in apart-hotels:

1 . The rooms in such hotels have a large area, which allows accommodating a group of people;

2. There is a whole kitchen for cooking; 
3. The possibility of a long rental. Rooms in such hotels can be rented for a sufficiently long and indefinite period;

4. Complete freedom of action. It is possible to invite your friends and acquaintances;

5. Since the living room is quite large, it becomes possible to choose a room with a beautiful view outside the window; hotel;

6 . The cost of renting a room in an apart-hotel is much cheaper than the cost of renting a

7.If desired, you can use the hotel services, such as housekeeping, laundry and room service.

8. There is an opportunity to use the services of a beauty salon, visit a fitness center, SPA and much more.

Table 1. Comparison of the service provided by the hotel and apart-hotel.

\begin{tabular}{|l|l|l|}
\hline \multicolumn{1}{|c|}{ Service } & \multicolumn{1}{|c|}{ Hotel } & \multicolumn{1}{c|}{ Apart-hotel } \\
\hline Services & Full range of services & Partial or full service \\
\hline Reception & Yes & Yes \\
\hline Breakfast & Everyday & At the request of the guest \\
\hline Kitchen & Not provided furniture, refrigerator, & Yes \\
\hline In the room & $\begin{array}{l}\text { New furt have a kitchen, the rest } \\
\text { individual air conditioning, TV, } \\
\text { comfortable wardrobe, spacious } \\
\text { bathroom }\end{array}$ & $\begin{array}{l}\text { depart-hotel the class of the } \\
\text { ath }\end{array}$ \\
\hline Cleaning & Yes & Yes \\
\hline
\end{tabular}

Despite all the advantages, accommodation in apart-hotels has a number of disadvantages [8].

1. Formally, apart-hotels are not housing. By law, this is commercial real estate, that is, the land on which such houses are built is reserved for non-residential buildings. Due to the fact that the developer uses such a loophole in the legislation, tenants cannot get a permanent residence permit.

2. Higher property tax compared to residential real estate;

3. The tariffs for utilities for commercial facilities are about a third higher than for residential ones;

4. Lack of a sufficient number of social facilities near the house.

These shortcomings can be eliminated through the formation and legislative consolidation of the rental housing market; creating legal mechanisms for obtaining permanent registration for residents of apart-hotels; development of tax legislation regarding the reduction of apartment tariffs and the creation of a mechanism for obtaining a tax deduction for the purchase of apartments.

The problem of forecasting at all times remains one of the most relevant, since the prediction of an uncertain future can reduce the degree of risk and adequately manage business processes [9]. The correct forecast on the real estate market is of great importance for all its participants.

Currently, there are more than one hundred forecasting methods. That is why the task of choosing methods that would give adequate forecasts for the processes or systems under study is very important.

Real estate markets by their nature differ markedly from those markets that are commonly called highly organized in economic science (for example, the securities market) [7]. Due to the private nature of transactions, real estate markets are often characterized by inaccessibility, incompleteness and inaccuracy of information received about it. Due to the significant informational closure of the real estate market, the role of irrational factors affecting decision making is significant. That is why, when forecasting the real estate 
market, one has to take into account the psychological motives of the behavior of its participants. It is also necessary to take into account the peculiarities of mentality when comparing real estate markets in different countries [10].

The main quantitative indicators are forecasted on the real estate market, such as property prices, volumes of real estate commissioned, sales volumes, etc. However, the key predicted indicator is price as a guideline for all market participants to make decisions.

They single out a fundamental and technical approach for forecasting the value of commercial real estate. When using the fundamental approach, much attention is paid to the choice of pricing factors at various levels, while new indicators and methods are developed during technical analysis with the development of computer technologies.

The combination of fundamental and technical analysis in the real estate market seems to be most justified due to the features associated with the use of real estate, as well as with the laws of market development. The fundamental nature of the property does not allow moving the goods to the buyer and thereby determines the local nature of the development of real estate markets. Real estate as an asset has real value, which is a certain security in real estate transactions. Another feature of the development of the real estate market is its inertia. Accordingly, any changes reflected in any way on prices occur much more slowly than in other markets.

Fundamental analysis of the real estate market allows you to determine the current stage of market development, pricing factors and the degree of their influence in a given period of time, as well as the trends that determine the future development of the market [11].

In order to most accurately predict market behavior and, above all, prices, it is necessary to determine at what point in time the expected changes will occur and how strong they will be. The duration and amplitude of the oscillations allow us to predict the methods of technical analysis. At the same time, the application of technical analysis should not be reduced to a simple approximation of the retrospective values of the indicator, it should be based on hypotheses regarding the nature of the development of the real estate market.

When forecasting the real estate market, it is advisable to use the following methods of technical analysis: comparative method, index method, method of non-harmonic decomposition of the price trend, method of regression analysis.

The comparative method is based on comparing the dynamics of several indicators on one chart. In the real estate market, this method is relevant due to the lag in price dynamics here compared to the stock market [12]. In addition, the fundamental nature of real estate determines the local nature of the development of real estate markets. This is expressed in the lead or delay in price dynamics of real estate markets in various cities (regions). These patterns are identified in the analysis of graphs and are used later in forecasting [13].

The index method in the real estate market is a forecasting method, which boils down to studying the dynamics of the price growth rate (price growth index). The future level of prices in the real estate market is determined by multiplying the forecast indices by the current price level.

Predicting the dynamics of the price growth index can be reduced to regression analysis or to the decomposition of the price trend [14].

The method of inharmonious decomposition of the price trend comes down to the transition from studying the dynamics of the studied value (prices in fact) to researching the first (growth, or growth rate), then the second (growth growth rate, or accelerating price growth), etc. derivative - dynamic series of growth rates of quantities relative to the approximating function of the previous level [15].

The method of regression analysis in the real estate market is a method for predicting the price dynamics of the real estate market, based on the study of changes in this dynamics in the past by constructing multiple regression [16]. A forecasting method based on a statistical regression model is to use a dynamic series of price level values to build a 
statistical process model and obtain an extrapolation forecast based on it. Moreover, if the form of the equation of the regression model was not determined by the analyst by selecting the appropriate smoothing, but on the basis of the hypothesis about the possible nature of the process to be simulated, then such a model can have significant predictive ability [17].

\section{Results}

The application of these methods, taking into account the theory of cycles and other patterns of development of the real estate market, allows you to get fairly close results, which gives confidence in the correctness of the assumptions made about the future development of the market [18].

Table 2. Factors affecting the average price per square meter of St. Petersburg apartments for 20142019.

\begin{tabular}{|c|c|c|c|c|c|c|}
\hline Year & $\begin{array}{l}\text { The average cost } \\
\text { per sq. m of service } \\
\text { ppartments, rub./m } \\
(y)\end{array}$ & $\begin{array}{l}\text { Number } \\
\text { f tourists, } \\
\text { mln. }\left(x_{1}\right)\end{array}$ & $\begin{array}{l}\text { The average cost of } \\
\text { rental housing in } \\
\text { the region, rubles / } \\
\text { month }\left(x_{2}\right)\end{array}$ & $\begin{array}{l}\text { The average per } \\
\text { apita cash income } \\
\text { of the population, } \\
\text { rub. }\left(x_{3}\right)\end{array}$ & $\begin{array}{c}\text { Weighted } \\
\text { average } \\
\text { mortgage } \\
\text { rate, \% }\left(x_{4}\right)\end{array}$ & $\begin{array}{l}\text { Supply } \\
\text { dynamics, } \\
\text { thousand } \\
\mathbf{m}^{2}\left(\mathbf{x}_{5}\right)\end{array}$ \\
\hline 2014 & 120 & 6.3 & 24620 & 34724 & 12.5 & 98 \\
\hline 2015 & 124 & 6.5 & 24118 & 39935 & 12.5 & 150 \\
\hline 2016 & 127 & 7.0 & 24683 & 41166 & 13.2 & 198 \\
\hline 2017 & 140 & 7.5 & 24813 & 41803 & 12.1 & 330 \\
\hline 2018 & 141 & 8.2 & 24728 & 42823 & 10.7 & 260 \\
\hline 2019 & 148 & 8.4 & 25964 & 43519 & 9.68 & 410 \\
\hline
\end{tabular}

To determine the relationship between these indicators, a correlation matrix was built (table 3).

Table 3. The correlation matrix.

\begin{tabular}{|c|c|c|c|c|c|c|}
\hline & $\boldsymbol{y}$ & $\boldsymbol{x}_{\boldsymbol{1}}$ & $\boldsymbol{x}_{\mathbf{2}}$ & $\boldsymbol{x}_{\mathbf{3}}$ & $\boldsymbol{x}_{\boldsymbol{4}}$ & $\boldsymbol{x}_{\mathbf{5}}$ \\
\hline$y$ & 1 & & & & & \\
\hline$x_{1}$ & $\mathbf{0 . 9 6 8 5 6 5 8 9 7}$ & 1 & & & & \\
\hline$x_{2}$ & 0.765091401 & 0.742943 & 1 & & & \\
\hline$x_{3}$ & 0.841626495 & 0.847472 & 0.484381 & 1 & & \\
\hline$x_{4}$ & -0.843902118 & -0.85891 & -0.77959 & -0.57575 & 1 & \\
\hline$x_{5}$ & 0.963476194 & 0.889416 & 0.81512 & 0.825892 & -0.75132 & 1 \\
\hline
\end{tabular}

Almost all indicators have a high relationship with the resulting indicator, many factors also have a relationship. The greatest influence on y is exerted by factor $x_{1}$ - the number of tourists annually visiting the city of St. Petersburg. The exception is the weighted average mortgage rate, which has an inverse correlation with the resulting indicator and is equal to 0.84 . High multicollinearity is observed between the factors $x_{1}$ and $x_{5}$, but we will not exclude them from the model, since their influence on the factor y individually is greater than the correlation between them $(0.96>0.88)$. In addition to factor $x_{4}$, it is also necessary to exclude factor $x_{\mathrm{a}}$ from the model, since if we consider this indicator in the general model together with factor $x_{1}$, then the correlation between these factors is greater than their correlation with the resulting indicator.

To build a further model, factors $x_{1}, x_{2}$ and $x_{5}$ were used - the number of tourists visiting the city of St. Petersburg annually; the average cost of rental housing in the region; dynamics of the offer of apartments in St. Petersburg.

The equation of the resulting indicator has the form:

$$
y=b_{0}+b_{1} \cdot x_{1}+b_{2} \cdot x_{2}+b_{9} \cdot x_{2},
$$

where $y$-resulting indicator (average price per square meter, rub.); 
$b_{0}, b_{1}, b_{2}, b_{2}-$ regression coefficients;

$x_{1}, x_{2}, x_{3}$ - factors determining the resulting indicator (rub.)

In the table 4 presents data to search for the necessary coefficients.

Table 4. Data for the search for coefficients

\begin{tabular}{|c|c|c|c|c|}
\hline $\begin{array}{c}\text { Yea } \\
\mathbf{r}\end{array}$ & $\boldsymbol{y}$ fact & $\begin{array}{c}\text { Number of } \\
\text { tourists, } \boldsymbol{x}_{\boldsymbol{I}}\end{array}$ & $\begin{array}{c}\text { The average cost of } \\
\text { rental housing, } \boldsymbol{x}_{\boldsymbol{2}}\end{array}$ & $\begin{array}{c}\text { Dynamics of the } \\
\text { offer of } \\
\text { apartments, } \boldsymbol{x}_{\boldsymbol{5}}\end{array}$ \\
\hline 2014 & 120 & 6.3 & 24620 & 98 \\
\hline 2015 & 124 & 6.5 & 24118 & 150 \\
\hline 2016 & 127 & 7 & 24683 & 198 \\
\hline 2017 & 140 & 7.5 & 24813 & 330 \\
\hline 2018 & 141 & 8.2 & 24728 & 260 \\
\hline 2019 & 148 & 8.4 & 25964 & 410 \\
\hline
\end{tabular}

\section{Discussion}

According to the data in Table 4, statistics for a series using the least squares method were calculated and the necessary $b_{0}, b_{1}, b_{2}, b_{2}$ were found: (110.13), (6.95), (-0.00163), (0.53). Based on the available data, a graph of the calculated resulting indicator was constructed (Fig. 4). This graph clearly demonstrates the high convergence between the calculated and the actual resulting indicator. In addition, to verify the resulting equation, the standard deviations of the actual and calculated indicators were calculated and $99 \%$ accuracy of the calculation model was obtained.

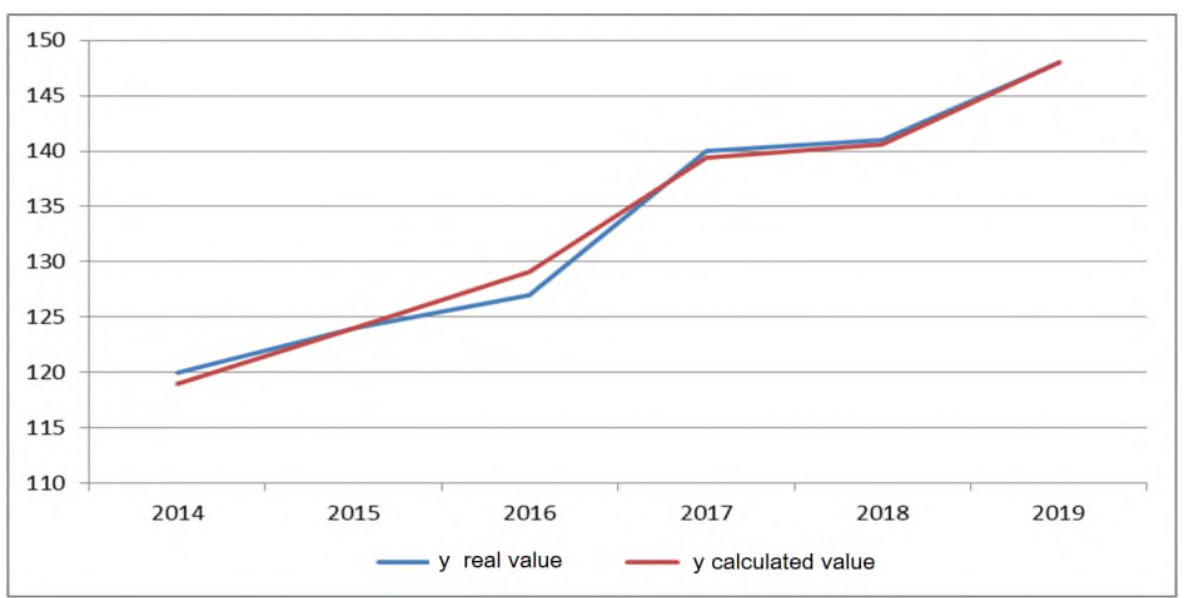

Fig. 4. Loading room stock of apart-hotels of St. Petersburg.

Using the method of exponential smoothing, changes in factors in the forecast period were predicted, and the obtained values were substituted into the developed model.

Exponential smoothing is carried out according to the formula:

$$
S_{t}=(1-\alpha) y_{t}+\alpha S_{t-1}
$$

$S_{t}$ - smoothed level values;

$y_{1}, y_{2}, y_{b}, \ldots y_{n}-$ source time series;

$t$ - values from 1 to $\mathrm{n}$;

$\alpha$ - smoothing parameter, determined by the formula: 


$$
\alpha=\frac{2}{(n+1)}
$$

The initial parameter was taken equal to the value of the first level of the series.

$S_{0}$ - the average value of the analyzed factors for 2014-2019.

$S_{1}$ - the average value of the exponential average of 1 order for 2014-2019.

The calculations are presented in tables 5-7.

Table 5. Calculation of the predicted value of factor $\mathrm{x}_{1}$ by the method of exponential smoothing.

\begin{tabular}{|c|c|c|c|}
\hline Year & $\begin{array}{c}\text { Number of } \\
\text { tourists, } \mathbf{x}_{\mathbf{1}}\end{array}$ & $\begin{array}{c}\text { Exponential average of } \\
\mathbf{1} \text { order }\end{array}$ & $\begin{array}{c}\text { Exponential average of } \\
\mathbf{2} \text { order }\end{array}$ \\
\hline 2014 & 6.3 & 7.0218 & 7.1220 \\
\hline 2015 & 6.5 & 6.8705 & 7.0491 \\
\hline 2016 & 7 & 6.9080 & 7.0082 \\
\hline 2017 & 7.5 & 7.0797 & 7.0289 \\
\hline 2018 & 8.2 & 7.4046 & 7.1378 \\
\hline 2019 & 8.4 & 7.6932 & 7.2989 \\
\hline 2020 & 8.2486 & 7.8543 & 7.4600 \\
\hline 2021 & 8.4097 & 8.0153 & 7.6210 \\
\hline 2022 & 8.5707 & 7.0218 & 7.1220 \\
\hline $\mathrm{a}=0.29$ & $\mathrm{~s} 0=7.316666667$ & $\mathrm{~s} 1=7.162996$ \\
\hline
\end{tabular}

Table 6. Calculation of the predicted value of factor $x_{2}$ by the method of exponential smoothing.

\begin{tabular}{|c|c|c|c|}
\hline Year & $\begin{array}{c}\text { Average } \\
\text { rental price, } \\
\boldsymbol{x}_{\mathbf{2}}\end{array}$ & $\begin{array}{c}\text { Exponential average } \\
\text { of 1 order }\end{array}$ & $\begin{array}{c}\text { Exponential average } \\
\text { of 2 order }\end{array}$ \\
\hline 2014 & 24620 & 24762.71 & 24736.16 \\
\hline 2015 & 24118 & 24575.74 & 24681.94 \\
\hline 2016 & 24683 & 24606.84 & 24690.96 \\
\hline 2017 & 24813 & 24666.63 & 24708.29 \\
\hline 2018 & 24728 & 24684.42 & 24713.46 \\
\hline 2019 & 25964 & 25055.50 & 24821.07 \\
\hline 2020 & 25385.69 & 25151.26 & 24848.84 \\
\hline 2021 & 25577.20 & 25274.78 & 24884.66 \\
\hline 2022 & 25824.26 & 24762.71 & 24736.16 \\
\hline$a=0.29$ & \multicolumn{3}{|c|}{$s_{1}=24821$} \\
\hline
\end{tabular}

Table 7. Calculation of the predicted value of factor $x_{5}$ by the method of exponential smoothing.

\begin{tabular}{|c|c|c|c|}
\hline Year & $\begin{array}{c}\text { Supply } \\
\text { Dynamics, } \boldsymbol{x}_{\mathbf{5}}\end{array}$ & $\begin{array}{c}\text { Exponential average } \\
\text { of } \mathbf{1} \text { order }\end{array}$ & $\begin{array}{c}\text { Exponential average } \\
\text { of 2 order }\end{array}$ \\
\hline 2014 & 98 & 199.53 & 215.2757 \\
\hline 2015 & 150 & 185.1663 & 206.5439 \\
\hline 2016 & 198 & 188.8881 & 201.4237 \\
\hline 2017 & 330 & 229.8105 & 209.6559 \\
\hline 2018 & 260 & 238.5655 & 218.0397 \\
\hline 2019 & 410 & 288.2815 & 238.4098 \\
\hline 2020 & 358.5233 & 308.6516 & 258.7799 \\
\hline 2021 & 378.8934 & 329.0217 & 279.1501 \\
\hline 2022 & 399.2635 & 199.53 & 215.2757 \\
\hline $\mathrm{a}=0.29$ & $\mathrm{~s}_{0}=241$ & $\mathrm{~s}_{1}=221.707$ \\
\hline
\end{tabular}


The obtained forecast values were substituted into the developed model. The final results are shown in table 8 and on the graph (Figure 5).

Table 8. Forecast values of the cost of service apartments.

\begin{tabular}{|c|c|c|c|}
\hline Year & $\begin{array}{c}\text { The average cost per sq. } \\
\text { m of service apartments, } \\
\text { thousand rubles } / \mathbf{~ m}^{\mathbf{2}}\end{array}$ & Year & $\begin{array}{c}\text { The average cost per } \\
\text { sq. m of service } \\
\text { apartments, thousand } \\
\text { rubles / } \mathbf{~ m}^{\mathbf{2}}\end{array}$ \\
\hline 2014 & 120 & 2019 & 148 \\
\hline 2015 & 124 & $\begin{array}{c}2020 \\
\text { (forecast) }\end{array}$ & 145 \\
\hline 2016 & 127 & 2021 (forecast) & 147 \\
\hline 2017 & 140 & 2022 & 149 \\
(forecast) & \\
\hline 2018 & 141 & & \\
\hline
\end{tabular}

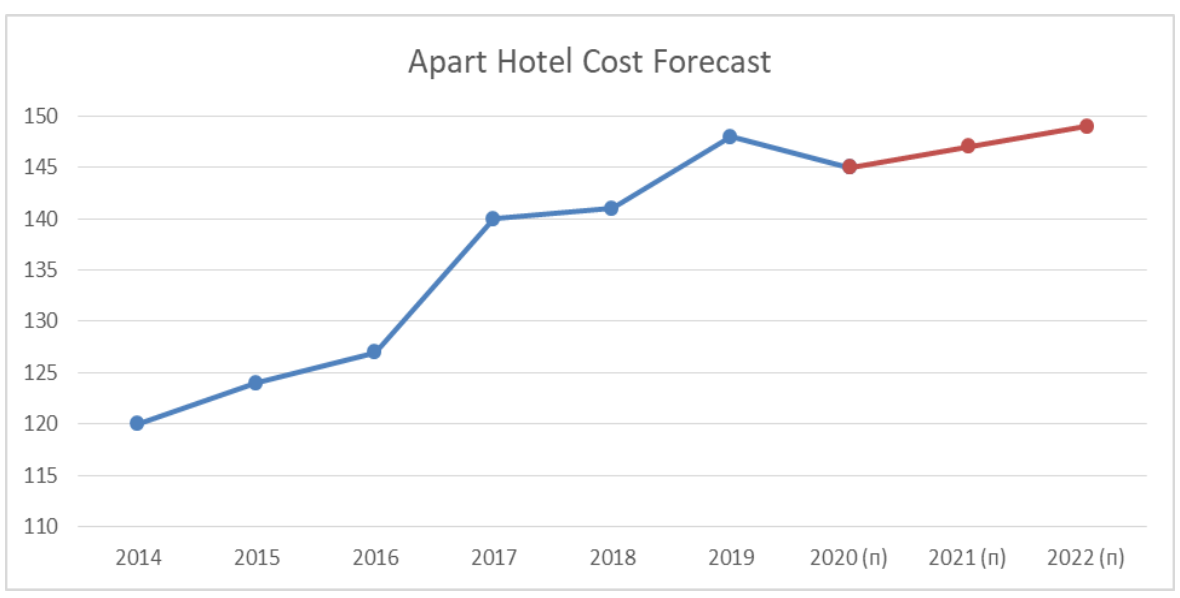

Fig. 5. The average cost per sq. $m$ of service apartments of St. Petersburg.

Based on the study, we can conclude that the market for service apartments will continue its further growth. In 2020 and 2021, the average price per square meter will fall slightly due to the ever-increasing development and variety of supply, but by 2022 the price will reach 149 thousand rubles $/ \mathrm{m}^{2}$.

\section{Conclusion}

Apart-hotels are a new trend in the real estate market. Every year, the offer of apartments and the load of rooms is growing. The market for service apartments is developing especially fast. The regression analysis made it possible to predict prices for this real estate segment. The values obtained indicate a further increase in prices for service apartments. The popularity of apartments in St. Petersburg will be largely due to an increase in tourist flow. In addition, the development of apartments in 2020 and beyond will largely determine the land market in the city. We are talking about land, which is located in locations with good transport accessibility, but it is impossible to build residential real estate on it, only apartments. That is why apartment projects in St. Petersburg have excellent prospects. 


\section{References}

1. O. Pirogova, E. Gorin and V. Plotnikov, The algorithms for the environmental finance based on adjusted present value models, E3S Web of Conferences 91, 08021 (2019)

2. V. Plotnikov and O. Pirogova, Key Competencies as an Enterprise Value Management Tool, IBIMA 2018 (2018)

3. J. Yoshida, The economic depreciation of real estate: Cross-sectional variations and their return implications, Pacific-Basin Finance Journal 61, 101290 (2020) https://doi.org/10.1016/j.pacfin.2020.101290

4. V. Skribans, M. Jurušs, M. Demianchuk, N. Maslii and D. Pastory. Real estate announcements monitoring dataset for Latvia 2018, Data in Brief 28, 105064 (2020) https://doi.org/10.1016/j.dib.2019.105064

5. M. Ardolino, M. Rapaccini, N. Saccani, P. Gaiardelli, G. Crespi and C. Ruggeri, The role of digital technologies for the service transformation of industrial companies, International Journal of Production Research 56(6) (2018) https://doi.org/10.1080/00207543.20171324224

6. M. Martín-Peña, J. Sánchez-López and E. Díaz-Garrido, Servitization and digitalization in manufacturing: the influence on firm performance, Journal of Business \& Industrial Marketing 35(3), 564-574 (2019) https://doi.org/10.1108/JBIM-12-2018-0400

7. E. Fang, W.R. Palmatier and J.-B.E. Steenkamp, Effect of Service Transition Strategy on Firm Value, Journal of Marketing 72, 1-14 (2008) https://doi.org/10.1509/jmkg.72.5.1

8. M.M. Hasan, Corporate life cycle, organizational financial resources and corporate social responsibility, Journal of Contemporary Accounting \& Economics 13, 20-36 (2017) https://doi.org/10.1016/j.jcae.2017.01.002

9. K.M. Bakarich, M. Hossain and J. Weintrop. Different time, different tone: Company life cycle, Journal of Contemporary Accounting and Economics 15(1), 69-86 (2019) https://doi.org/10.1016/j.jcae.2018.12.002

10. A.R. Bril, O.V. Kalinina, and O.V. Rasskazova, Financial and economic aspects of the assessment of innovative projects in the human resource management system, IBIMA (2018)

11. O. Pirogova, V. Plotnikov and Z. Popovic, The Multi-level Model of the Service Enterprises Human Capital Value. (Eds.): TransSiberia 2019, AISC 1116 (2020) https://doi.org/10.1007/978-3-030-37919-3_73

12. A.A. Salisu, I.D. Raheem and U.B. Ndako, The inflation hedging properties of gold, stocks and real estate: A comparative analysis, Resources Policy 66, 101605 (2020) https://doi.org/10.1016/j.resourpol.2020.101605

13. Ya. Li, D. Zhu, J. Zhao, X. Zheng and L. Zhang, Effect of the housing purchase restriction policy on the Real Estate Market: Evidence from a typical suburb of Beijing, China, Land Use Policy 94, 104528 (2020) https://doi.org/10.1016/ j.landusepol.2020.104528

14. Ch. Liu, Y. Zheng, Q. Zhao and Ch. Wang, Financial stability and real estate price fluctuation in China, Physica A: Statistical Mechanics and its Applications 540, 122980 (2020) https://doi.org/10.1016/j.physa.2019.122980

15. B. Carmichael and A. Coën, Real estate as a common risk factor in the financial sector: International evidence, Finance Research Letters 32, 101172 (2020) https://doi.org/10.1016/j.frl.2019.04.029 
16. A. Eggert, J. Hogreve, W. Ulaga, and E. Muenkhoff, Revenue and profit implications of industrial service strategies, Journal of Service Research 17(1), 23-39 (2014) https://doi.org/10.1177/1094670513485823

17. E. Brynjolfsson, and L.M. Hitt, Beyond Computation: Information Technology, Organizational Transformation, and Business Performance, Journal of Economic Perspectives 14(4), 23-48 (2000) http://dx.doi.org/10.1257/jep.14.4.23

18. C. Kowalkowski, H. Gebauer, and R. Oliva, Service growth in product firms: past, present, and future, Industrial Marketing Management 60, 82-88 (2017) http://dx.doi.org/10.1016/j.indmarman.2016.10.015 